\title{
Substitution of Complete Feed with Hydroponic Corn Fodder on Rumen Characteristics and Nitrogen Dynamics in Goats
}

\author{
${ }^{1}$ Muh Shoalihin Saleh Husain, ${ }^{2}$ Syahriani Syahrir, ${ }^{2}$ Asmuddin Natsir \\ ${ }^{1}$ Postgraduate of Animal Science Department, University of Hasanuddin \\ ${ }^{2}$ Animal Science Department, University of Hasanuddin
}

Received date: 19 July 2018, Accepted date: 15 August 2018, Online date: 1 September 2018

\author{
Address for Correspondence: \\ Muh Shoalihin Saleh Husain, Postgraduate student of Animal Science Department, University of Hasanuddin, Makassar, 90245 , \\ Indonesia. \\ E-mail: muhshoalihinsaleh@yahoo.co.id
}

Copyright () 2018 by authors and American-Eurasian Network for Scientific Information.

This work is licensed under the Creative Commons Attribution International License (CC BY).

http://creativecommons.org/licenses/by/4.0/

\section{(c) () Open Access}

\begin{abstract}
This research used a Randomized Block Design by using 12 goats. The purpose of this research is to examine the effect of complete feed substituted with hydroponic corn fodder on rumen characteristics and nitrogen dynamics. Feeding with three treatments P1 (complete feed), P2 (corn fodder) and P3 (50\% P1 + 50\% P2). Data were analyzed using analysis of variance (anova). Variables measuring rumen characteristics $(\mathrm{pH}, \mathrm{VFA}$ and $\mathrm{NH} 3$ ) and nitrogen balance $(\mathrm{N}$ consumption, $\mathrm{N}$ digestibility, urine $\mathrm{N}$ and $\mathrm{N}$ retention). The results of this research indicate that effective feed is given to goat livestock in P3 treatment $(50 \% \mathrm{P} 1+50 \% \mathrm{P} 2)$ characterized by the optimum $\mathrm{pH}$ value (6.67) and VFA (112.82 mM), compared to P1 (complete feed) and P2 (corn fodder) with pH value (7.22), (6.94) and VFA value $(103.84 \mathrm{mM}),(93.85 \mathrm{mM})$. And followed by high levels of digestibility $\mathrm{N}(77.10 \%)$ and low urine $\mathrm{N}(0.27 \mathrm{~g} / \mathrm{e} /$ h). The conclusion is that the effective feed given to livestock is feed with P3 treatment.
\end{abstract}

\section{KEY WORDS}

Complete feed, hydroponic corn fodder, rumen characteristics, nitrogen balance, goats.

\section{INTRODUCTION}

Feed with high nutritional content that meets the needs of goats will produce good productivity. According to [1] goats with body weight between $10-20 \mathrm{~kg}$ (average of $15 \mathrm{~kg}$ ), to produce PBBH between $50-100 \mathrm{~g} / \mathrm{h}$ (average $75 \mathrm{~g}$ ) requires consumption of dry feed between 470-620 g (average $545 \mathrm{~g}$ ) crude protein between 44$58 \mathrm{~g}$ (average $51 \mathrm{~g}$ ) and energy can be digested between 1,380-1,820 Mkal/e/h with an average of 1,600 Mkal.

Efforts to improve the quality of livestock are carried out by utilizing technological advances in the field of feed, by making a complete feed formulation. Complete feed is now a discourse that continues to be researched and tried by livestock practitioners and researchers. The use of complete feed provides more benefits for daily weight gain and the duration of livestock fattening is really only in a short time and also provides financial benefits [2].

Requirements for a good complete feed must fulfill a balanced and adequate nutrient content in accordance with the needs of livestock. The nutrient content that needs to be considered, one of them is the presence of protein and crude fiber which serves as an energy source, helps the performance or function of the rumen therefore it can increase digestibility.

Hydroponic for production different crops [3] and particularly corn fodder can be used as an alternative technology for producing forage feed. Hydroponic techniques have the ability to produce quality products. In 
addition, hydroponics systems are not dependent on the season therefore plants can be planted throughout the year and can be planted on narrow land with a greenhouse system [5].

Feed digestion metabolism in goat livestock can be seen in rumen characteristics (VFA, pH, and NH3) and nitrogen dynamics ( $\mathrm{N}$ consumption, $\mathrm{N}$ digestibility and $\mathrm{N}$ retention). This research examines the effects of complete feed combined with Hydroponic Corn Fodder on rumen characteristics (VFA, pH, and NH3) and nitrogen dynamics ( $\mathrm{N}$ consumption, $\mathrm{N}$ digestibility, urine $\mathrm{N}$ and $\mathrm{N}$ retention) in goat livestock.

\section{MATERIAL AND METHOD}

This research was conducted from March to May 2018. The in vivo test research included the rumen characteristics and nitrogen dynamics of goats that received complete feed substituted with hydroponic corn fodder. The research was conducted at the Animal Science Faculty of University of Hasanuddin (Cages of experimental feed and livestock maintenance tests and Feed Chemical Laboratory for sample analysis).

Making Hydroponic corn fodder, the seeds are soaked using $50^{\circ} \mathrm{C}$ warm water and let it set for 24 hours. The soaked corn is then spreader on a tray. Each tray contains 250 grams of seed. Corn seeds are watered regularly every hour, for a minute from 6:00 a.m. to 10:00 p.m. every day, the harvest was done on the 9th day.

The making of complete feed first collects conventional feed ingredients and then analyze at the Feed Chemical Laboratory to see the nutritional content of each feed ingredient. After the nutritional content of each feed ingredient has been known, it is continued to prepare ration with a protein content of $10-12 \%$ and a moisture content of 30-40\%. After determining the composition of the use of each feed ingredient, then mixing the feed ingredients, feed ingredients that have been mixed, weighed as much as $5 \mathrm{~kg}$, packed in plastic bags and stored in sacks of each sample.

The livestock used were 12 male goats. Feed is given twice a day at 08.00 and 16.00 WITA (Central Indonesian Time). Drinking water is given ad libitum. Maintenance is carried out for 23 days (18 days of adaptation and 5 days of collection period) during maintenance given 3 feeds. P1 (complete feed), P2 (Hydroponic corn fodder) and P3 (50\% P1 + 50\% P2).

The variables observed at this research stage were rumen characteristics (pH, VFA, and NH3), and protein dynamics ( $\mathrm{N}$ consumption, $\mathrm{N}$ digestibility, urine $\mathrm{N}$ and $\mathrm{N}$ retention).

$N_{3}=\frac{V \cdot N \cdot 17}{1000} \times 100 \%$

Total VFA concentration $(\mathrm{mM})=(\mathrm{a}-\mathrm{b}) \times \mathrm{N} \mathrm{HCl} \times 1000 / 5 \mathrm{ml}$

Information: $\mathrm{a}=$ titran blank o volume $(\mathrm{ml}), \mathrm{b}=$ titran sample volume $(\mathrm{ml})$

Nitrogen consumption $(\mathrm{g} / \mathrm{e} / \mathrm{h})=$ contents of $\mathrm{N} \times$ intake BK

$\mathrm{N}$ Digestibility $(\%)=\frac{\mathrm{N} \text { consumed }-\mathrm{N} \text { feces }}{\mathrm{N} \text { consumed }} \times 100 \%$

$\mathrm{N}$ Retention $(\mathrm{g} / \mathrm{e} / \mathrm{h})=\mathrm{N}$ consumed $-\mathrm{N}$ feces $-\mathrm{N}$ urine

In this research using a Randomized Block Design (RBD) with 3 treatments and 4 groups. If the effect is significant, Duncan test is carried out [4]. The mathematical model used is as follows:

$\mathrm{Yij}=\mathrm{u}+\tau \mathrm{i}+\beta \mathrm{j}+€_{\mathrm{ij}} \quad ; \mathrm{i}=1,2,3$

$\mathrm{j}=1,2,3,4$

Information: $\mathrm{Yij}=$ the observation value of the $\mathrm{i}$-treatment in the j-group,

$\mathrm{u}=$ middle value of population (population mean)

$\tau \mathrm{i}=$ additive effect from the I-treatment,

$\beta \mathrm{j}=$ additive effect of the $\mathbf{j}$-group,

$€ \mathrm{ij}=$ experimental defect effect of the $\mathrm{i}$-treatment in the $\mathrm{j}$-group.

\section{RESULT AND DISCUSSION}

The effect of treatment on the characteristics of rumen liquid (pH, NH3 and VFA) is shown in Table 1. Analysis of Variance showed that the Rumen $\mathrm{P} 1 \mathrm{pH}$ was significantly different $(\mathrm{P}<0.05)$ from R3 treatment, but not significantly different $(\mathrm{P}>0.05)$ with $\mathrm{P} 2$. And $\mathrm{P} 2$ is not significantly different $(\mathrm{P}>0.05)$ with $\mathrm{P} 3$. Analysis of Variance showed Rumen NH3 and VFA were not significantly different $(\mathrm{P}>0.05)$ in each treatment

The results showed that $\mathrm{pH}$ was $6.6-7.2$, at the optimum $\mathrm{pH}$ range, therefore it would be able to give a good impact on the rumen feed degradation process. This is in accordance with the opinion [6], which states that it is categorized into optimal $\mathrm{pH}$ in the range of 6.9 to 7.0. This is one indicator of the occurrence of a good feed degradation process, because at this $\mathrm{pH}$, microbes producing digestive enzymes of crude fiber, can live optimally in the rumen. 
Table 1: Rumen fluid characteristics of goats that is fed complete feed substituted with hydroponic corn fodder.

\begin{tabular}{|l|l|l|l|}
\hline \multirow{2}{*}{ Parameter } & Treatment & $\mathrm{P} 2$ & $\mathrm{P} 3$ \\
\cline { 2 - 4 } & $\mathrm{P} 1$ & $6.94 \pm 0.29^{\mathrm{ab}}$ & $6.67 \pm 0.29^{\mathrm{b}}$ \\
\hline $\mathrm{pH}$ & $7.22 \pm 0.21^{\mathrm{a}}$ & $26.26 \pm 12.49$ & $17.16 \pm 7.80$ \\
\hline $\mathrm{NH}_{3}(\mathrm{mM})$ & $17.48 \pm 6.42$ & $93.85 \pm 8.72$ & $112.82 \pm 16.21$ \\
\hline VFA $(\mathrm{mM})$ & $103.84 \pm 36.10$ & $\mathrm{P}<0.05) ; \mathrm{P} 1=$ Complete feed, $\mathrm{P} 2=\mathrm{Hydroponic}$ corn fodder P3 \\
\hline
\end{tabular}
$=\mathrm{P} 150 \%+\mathrm{P} 250 \%$.

The ammonia concentration produced from the whole treatment ranged from 17.16-26.26 mM which showed that the NH3 concentration was higher than the optimum concentration. According to the opinion [6] which states that the optimum NH3 concentration needed to support microbial growth is $4-12 \mathrm{mM}$ (mean 8 $\mathrm{mM}$ ). If protein degradation is faster than microbial protein synthesis, NH3 will accumulate and exceed its optimum concentration [8]. Ammonia production in the rumen is affected by the solubility of feed ingredients, amount of ration protein, ration nitrogen source, rumen $\mathrm{pH}$ and time after feeding (maximum production is reached 2-4 hours after feeding) [9].

The highest VFA concentration was $112.82 \mathrm{mM}$ in P3 treatment, followed by $103.84 \mathrm{mM} \mathrm{P1}$ and P2 93.85 $\mathrm{mM}$. With VFA concentration in each treatment, it shows that VFA is still in the optimum range. VFA needed for an animal to grow normally is around $80-160 \mathrm{mM}$ [9]. In addition, the VFA concentration range is also sufficient to meet microbial needs to develop in the rumen [11].

Effect of treatment on rumen nitrogen dynamics (consumption of $\mathrm{N}, \mathrm{N}$ digestibility, urine $\mathrm{N}$ and retention of $\mathrm{N})$ Table 2. Analysis of Variance showed consumption of $\mathrm{N} P 2$ was significantly different $(\mathrm{P}<0.05)$ against $\mathrm{P} 1$ and $\mathrm{P} 3$, but $\mathrm{P} 1$ was not significantly different $(\mathrm{P}>0.05)$ against $\mathrm{P} 3$. Analysis of Variance showed $\mathrm{N}$ digestibility, $\mathrm{N}$ urine and $\mathrm{N}$ retention were not significantly different $(\mathrm{P}>0.05)$ in each treatment.

Table 2: Nitrogen balance in goats fed complete feed substituted with hydroponic corn fodder.

\begin{tabular}{|c|c|c|c|}
\hline \multirow{2}{*}{ Parameter } & \multicolumn{3}{|l|}{ Treatment } \\
\hline & P1 & \begin{tabular}{l|l} 
& P2
\end{tabular} & P3 \\
\hline N Consumption(g/e/h) & $10.07 \pm 7.82^{\mathrm{b}}$ & $4.20 \pm 2.19^{\mathrm{a}}$ & $8.68 \pm 3.28^{b}$ \\
\hline N Digestibility $\%$ & $72.86 \pm 6.40$ & $77.12 \pm 26.85$ & $77.10 \pm 15.12$ \\
\hline N Urine $(\mathrm{g} / \mathrm{e} / \mathrm{h})$ & $0.52 \pm 0.82$ & $0.49 \pm 0.37$ & $0.27 \pm 0.17$ \\
\hline Retention $(\mathrm{g} / \mathrm{e} / \mathrm{h})$ & $7.45 \pm 5.97$ & $2.71 \pm 1.68$ & $6.71 \pm 2.69$ \\
\hline
\end{tabular}

Information: Different letters on the same line show significantly different $(\mathrm{P}<0.05)$; P1 = Complete feed, P2 = Hydroponic corn fodder P3 $=\mathrm{P} 150 \%+\mathrm{P} 250 \%$.

The high level of nitrogen consumption in P1 treatment was followed by high levels of digestibility and nitrogen retention. This is in accordance with the opinion [12] states that the level of consumption of protein (nitrogen) is strongly influenced by the digestion coefficient, the quality or chemical composition of feed, fermentation in the rumen, movement of food through the digestive tract and physiological status of livestock.

The highest digestibility value was found in P2 then followed by treatment P3 and P1. Although the composition of the P1 ration was not different which was composed from the residual of agricultural waste, which contained higher crude fiber than P2 feed, which was sourced from fresh forage and P3 a combination of complete feed and corn fodder which had a lower digestibility value. [13] States that protein digestibility of food ingredients depends on protein ration content, food ingredients that are low in protein content have a low protein digestibility. Decreased nitrogen digestibility in animals is caused by lack of dissolved nitrogen or low digestibility of feed [14].

High $\mathrm{N}$ content in urine is also an indicator that the use of protein by livestock to meet their needs is not optimal. Thus high urine $\mathrm{N}$ is a parameter of inefficiency in the utilization of protein feed by livestock [15].

Basically, the supply of $\mathrm{N}$ has a higher potential for retention, if supported by the supply of energy in feed. $\mathrm{N}$ retention generated from the research is positive, means that the amount of $\mathrm{N}$ consumed is bigger than the amount of $\mathrm{N}$ that is released [16]. Factors that affect nitrogen supply are the quality of feed consumed by livestock, feed consumed by livestock to meet energy and protein needs.

\section{Conclusion:}

The provision of complete feed and hydroponic corn fodder as livestock feed has met NH3, VFA and pH values which are optimal for the development of microbes in goat rumen. Reviewed from the results of nitrogen balance values, then of the three most effective treatments were P3 treatment.

\section{ACKNOWLEDGEMENT}

The authors would like to thank the Rector of University of Hasanuddin, Prof. Dr. Dwia Aries Tina Pulubuhu M.A. and Post Graduate Program of Animal Science Department, University of Hasanuddin. And also thanks to author's supervisor and co-supervisor. Special thanks to CV. BenuaMaritim Indonesiafor their support 
in providing research materials. Other thanks to the technicians in the Feed Chemistry Laboratory of University of Hasanuddin for providing chemical.

\section{REFERENCES}

[1] National Research Council, 2006. Nutrient Requirements of Small Ruminants (Sheep, Goats, Cervids, and New World Camelids), Washington, D.C: National Academic Press.

[2] Rasyid, T. Giling, Amrullah T., Sofyan Nurdin Kasim, Ikrar Moh. Saleh, St. Rohani, 2018. Technology adoption of complete feed by livestock cow breeder. American-Eurasian Journal of Sustainable Agriculture, AEJSA.2018.12.1.1 p:1-4

[3] Al-Tawaha, A. R., Al-Karaki, G., Al-Tawaha, A. R., Sirajuddin, S. N., Makhadmeh, I., Wahab, P. E. M., Youssef, R. A., Al Sultan, W. \& Massadeh, A. (2018). Effect of water fl ow rate on quantity and quality of lettuce (Lactuca sativa L.) in nutrient fi $\mathrm{lm}$ technique (NFT) under hydroponics conditions. Bulgarian Journal of Agricultural Science, 24(5), 793-800

[4] Suhardiyanto, H., 2009. Green House Technology for the Tropical Wet climate: Environmental Modeling and Control. Bogor (ID): IPB Pres.

[5] Gaspersz, V., 1991. Experimental design method. Armico. Bandung.

[6] Jean-Blain, C., 1991. Rumen Disfunctions. In: Jouany, J.P. (ed), Rumen Microbial Metabolism and Ruminant Digestion. INRA Editions, Paris, pp: 361-364.

[7] Sutardi, T., A.S. Amirroenas, S.H. Tjakradidjaja, Dilaga and Jalaludin, 1993. Use of Chocolate Pods and Tree Leguminosa and Hydroxy Methionine Analog Supplementation and Defaunation in Ruminants. Presented at the Animal Husbandry Sector Research Results Communication Forum in Yogyakarta, 23-25.

[8] McDonald, P., R.A. Edward, J.F.D. Greenhalgh, C.A. Morgan, 2002. Animal Nutrition 6th ed., Gosport: Ashford Colour Press.

[9] Wohlt, J.E., J.H. Clark and F.S. Balaisdell, 1976. Effects of sampling location, time and method on concentration of ammonia nitrogen in rumen fluid. J. Dairy Sci., 59: 459-464.

[10] Suryapratama, W., 1999. Effect of branched volatile fatty acid supplementation and lysine capsule and threonine on protein nutrition of Holstein cows. Dissertation. Postgraduate Program, Bogor Agricultural Institute.

[11] Sutardi, T., 1980. Foundation for Nutrition Sciences 1st ed., Bogor: Animal Science Faculty. Bogor Agricultural Institute.

[12] Cole, H.H. and M. Ronning, 1970. Animal Agriculture. W. H. Freeman and Co., SanFransisco, pp: 515-531.

[13] Ranjhan, S., 1980. Animal Nutrition and Feeding Practices in India. 2nd Ed., New Delhi: Vikas Publishing House, pp: 93-104.

[14] Helal, G., M.S. Nassar, H.S. Badawy, E.Y. Eid and H.M. El Shaer, 2018. Comparative nutritional studies of sheep and goats fed cultivated tree legumes mixture under desert condition. . American-Eurasian Journal of Sustainable Agriculture, AEJSA. 12.1.3 p:10-21.

[15] Paulus K. Tahuk, E. Baliarti and H. Hartadi, 2008. The balance of Nitrogen and bligon goat blood urea content by fattening with different levels of feed protein. J.Indon.Trop.Anim. Agric. 33 [4] December 2008.

[16] McDonald, P., R.A. Edwards and J.F.D. Greenhalgh, 1988. Animal Nutrition. John Willey and Sons Inc., New York, pp: 96-105. 